University of Nebraska - Lincoln

DigitalCommons@University of Nebraska - Lincoln

\title{
Estimation of Undegradable Intake Protein in Forages Using Neutral Detergent Insoluble Nitrogen at a Single In Situ Incubation Time Point
}

\author{
H. L. Haugen \\ University of Nebraska-Lincoln \\ M. J. Lamothe \\ University of Nebraska-Lincoln \\ Terry J. Klopfenstein \\ University of Nebraska-Lincoln, tklopfenstein1@unl.edu \\ Don C. Adams \\ University of Nebraska-Lincoln, dadams1@unl.edu \\ M. D. Ullerich
}

Follow this and additional works at: https://digitalcommons.unl.edu/animalscifacpub

Part of the Animal Sciences Commons

\footnotetext{
Haugen, H. L.; Lamothe, M. J.; Klopfenstein, Terry J.; Adams, Don C.; and Ullerich, M. D., "Estimation of Undegradable Intake Protein in Forages Using Neutral Detergent Insoluble Nitrogen at a Single In Situ Incubation Time Point" (2006). Faculty Papers and Publications in Animal Science. 543.

https://digitalcommons.unl.edu/animalscifacpub/543

This Article is brought to you for free and open access by the Animal Science Department at DigitalCommons@University of Nebraska - Lincoln. It has been accepted for inclusion in Faculty Papers and Publications in Animal Science by an authorized administrator of DigitalCommons@University of Nebraska - Lincoln.
} 


\title{
Estimation of undegradable intake protein in forages using neutral detergent insoluble nitrogen at a single in situ incubation time point ${ }^{1}$
}

\author{
H. L. Haugen, M. J. Lamothe, T. J. Klopfenstein, ${ }^{2}$ D. C. Adams, and M. D. Ullerich \\ Department of Animal Science, University of Nebraska, Lincoln 68583-0908
}

\begin{abstract}
Two experiments were conducted to evaluate the use of neutral detergent insoluble nitrogen (NDIN) at a single in situ incubation time point to estimate the undegradable intake protein (UIP) in forages as well as to compare rates of NDIN degradation. Forage samples in Exp. 1 comprised diet samples collected from range and meadow pastures monthly from May through September. In Exp. 2, clipped samples of alfalfa, birdsfoot trefoil, kura clover, and smooth bromegrass, and diet samples of the mixed legume-grass and smooth bromegrass were evaluated. Forage samples were incubated in situ for their mean retention time (MRT) estimated from IVDMD plus a 10-h passage lag to yield the total MRT (TMRT). Samples were also incubated for $0 \mathrm{~h}, 10 \mathrm{~h}, 75 \% \mathrm{TMRT}$, and $96 \mathrm{~h}$. Undegradable intake protein was measured at $75 \%$ TMRT and TMRT, and calculated using fractional rates of degradation and passage with a 10 -h passage lag. Rates of ruminal NDIN degradation were calculated using the slope of the regression of the natural logarithm of the poten-
\end{abstract}

tially degradable NDIN remaining (96-h undegradable fraction subtracted) against time. The estimated UIP values obtained using 75\% TMRT were highly correlated with those obtained using fractional rates of degradation and passage plus accounting for a $10-\mathrm{h}$ passage lag in Exp. $1\left(R^{2}=0.95\right)$ and Exp. $2\left(R^{2}=0.98\right)$. Rates of NDIN degradation of range and meadow samples in Exp. 1 were slower $(P<0.05)$ from 0 to $10 \mathrm{~h}$ in May and June compared with rates from $10 \mathrm{~h}$ to $75 \%$ TMRT, but rates of degradation were not different $(P=$ 0.34 to 0.71 ) for the rest of the collection periods. Rates of degradation were not different from 0 to $10 \mathrm{~h}$ and 10 $\mathrm{h}$ to $75 \%$ TMRT in Exp. 2 for $\operatorname{diet}(P=0.82)$ or clipped samples $(P=0.86)$. The UIP of the forages in these experiments was accurately estimated using NDIN at a single in situ incubation time point equivalent to $75 \%$ of the TMRT, and rates of protein degradation can be obtained at this time point when 0 - and 96 -h incubations are included.

Key words: forage, neutral detergent insoluble nitrogen, undegradable intake protein

(C2006 American Society of Animal Science. All rights reserved.

J. Anim. Sci. 2006. 84:651-659

\section{INTRODUCTION}

The fraction of $\mathrm{CP}$ of feed that escapes ruminal degradation is the undegradable intake protein (UIP). Orskov and McDonald (1979) found that competing rates of passage $\left(\mathrm{k}_{\mathrm{p}}\right)$ and degradation $\left(\mathrm{k}_{\mathrm{d}}\right)$ ultimately determine the UIP of feed. The standard method of estimating the potentially digestible fraction of protein that escapes ruminal degradation uses a first-order disappearance model: UIP $=\left[\mathrm{B} *\left\{\mathrm{k}_{\mathrm{p}} /\left(\mathrm{k}_{\mathrm{p}}+\mathrm{k}_{\mathrm{d}}\right)\right\}\right]+\mathrm{C}($ Broderick, 1994). This approach assumes that ingested feed particles can pass out of the rumen immediately, even though some ingested forage particles may not be capa-

\footnotetext{
${ }^{1}$ A contribution of the University of Nebraska Agric. Res. Div., Lincoln, NE 68583. Journal Series No. 14706.

${ }^{2}$ Corresponding author: tklopfenstein1@unl.edu

Received October 7, 2004.

Accepted October 31, 2005.
}

ble of immediate escape from the rumen because of particle size and buoyancy of entrapped gasses.

Forage residues incubated in situ contain microbes that significantly contribute to residual DM and N (Nocek, 1985; 1988; Nocek and Grant, 1987). Mass et al. (1999) evaluated the use of NDF extraction as an alternative to the commonly used purine procedure (Zinn and Owens, 1986) to correct for microbial N, and Mass et al. (1999) showed that neutral detergent insoluble N (NDIN) from incubated residues was equal to total $\mathrm{N}$ of the residue corrected for purines. Previous work has suggested that forages be incubated in situ for their mean retention time (MRT) plus a 10-h passage lag (TMRT) for determination of the UIP fraction (Klopfenstein et al., 2001); however, further consideration of the forages in that particular article indicated that incubation of forages for their TMRT may underestimate UIP. Mathematically, it seems that a time point equivalent to $75 \%$ of the TMRT would more closely reflect the competing rates of passage and degradation on UIP values; therefore, it was hypothesized that re- 
Table 1. In vitro dry matter digestibilities, rates of passage, mean retention times, and in situ incubation times of upland range and meadow samples (Exp. 1)

\begin{tabular}{lcccc}
\hline \hline Forage/month & IVDMD & $\mathrm{k}_{\mathrm{p}},{ }^{1} \% / \mathrm{h}$ & $75 \% \mathrm{TMRT}^{2}$ & Incubation, $^{3} \mathrm{~h}$ \\
\hline Range & & & & \\
May & 67.7 & 4.54 & 4.0 & 24 \\
June & 63.6 & 4.25 & 25.2 & 27 \\
July & 61.6 & 4.11 & 25.7 & 27 \\
August & 55.8 & 3.71 & 27.9 & 27 \\
September & 52.5 & 3.48 & 29.5 & 31 \\
Meadow & & & & \\
May & 70.2 & 4.71 & 23.4 & 24 \\
June & 67.3 & 4.51 & 24.1 & 24 \\
July & 59.0 & 3.93 & 26.6 & 27 \\
August & 57.2 & 3.81 & 27.2 & 27 \\
September & 50.4 & 3.33 & 30.1 & 31 \\
SEM & 0.81 & & & \\
\hline
\end{tabular}

${ }^{1}$ Rate of passage $=0.07($ IVDMD $\%)-0.20$.

${ }^{2} 75 \%$ TMRT $=\left[\left(1 / \mathrm{k}_{\mathrm{p}}\right)+10\right] \times 0.75$.

${ }^{3}$ Actual in situ incubation time.

ducing the TMRT to 75\% TMRT would yield UIP values similar to the equation.

The objectives of this study were to 1) compare UIP estimates of forage samples at 75\% TMRT and TMRT using the NDIN procedure to equation values accounting for the rate of degradation and passage with a 10$\mathrm{h}$ passage lag, and 2) compare rates of NDIN degradation.

\section{MATERIALS AND METHODS}

\section{Forage Samples}

Upland native range and subirrigated meadow forages grown at the University of Nebraska Gudmunsen
Table 3. Rate of degradation $(\% / h)$ of neutral detergent insoluble $\mathrm{CP}$ of upland range and meadow samples collected from May through September from 0 to $10 \mathrm{~h}, 10$ $\mathrm{h}$ to $75 \%$ total mean retention time (TMRT), and $75 \%$ TMRT to TMRT (Exp. 1)

\begin{tabular}{lccr}
\hline \hline Forage/month & 0 to $10^{1}$ & $\begin{array}{c}10 \text { to } 75 \% \\
\text { TMRT }^{1,2}\end{array}$ & $\begin{array}{r}75 \% \text { TMRT } \\
\text { to TMRT }\end{array}$ \\
\hline Range & & & \\
May & 3.03 & 5.15 & 1.18 \\
June & 2.23 & 3.24 & 4.19 \\
July & 1.86 & 3.74 & 2.68 \\
August & 3.93 & 4.86 & 0.18 \\
September & 2.69 & 3.75 & 9.02 \\
Meadow & & & \\
May & 4.33 & 8.38 & 0.19 \\
June & 3.18 & 5.41 & -1.60 \\
July & 6.36 & 5.66 & 0.57 \\
August & 5.21 & 4.91 & 1.73 \\
September & 4.27 & 3.64 & 11.07 \\
SEM & 0.77 & 1.30 & 1.46 \\
\hline
\end{tabular}

${ }^{1}$ Month $\times$ incubation time $P<0.05$; month $\times$ forage type $P=0.09$.

${ }^{2}$ Month $\times$ incubation time $P<0.05$; forage type $\times$ incubation time $P<0.05$.

Sandhills Laboratory, Whitman, Nebraska, were collected from 2 pastures using 3 esophageally fistulated cows $(560 \mathrm{~kg})$ in Exp. 1. All animal procedures were approved by the University of Nebraska Animal Care and Use Committee. Diet samples were collected May 25, June 22, July 20, August 17, and September 21 of 2001. The dominant grass species in the range pasture were: little bluestem [Schizachyrium scoparium (Michx.) Nash], prairie sandreed [Calamovilfa longifolia (Hook.) Scribn.], sand bluestem [Andropogon gerardii var. paucipilus (Nash.) Fern], switchgrass (Panicum virgatum L.), sand lovegrass [Eragrostis trichodes

Table 2. Original CP and potentially degradable neutral detergent insoluble CP (\% DM) remaining of upland range and meadow samples collected from May through September (Exp. 1)

\begin{tabular}{|c|c|c|c|c|c|c|}
\hline \multirow[b]{2}{*}{ Forage/month } & \multirow[b]{2}{*}{ Original CP } & \multicolumn{5}{|c|}{ Incubation time } \\
\hline & & $0 \mathrm{~h}^{1}$ & $10 h^{1}$ & $75 \% \mathrm{TMRT}^{1,2}$ & $\mathrm{TMRT}^{1,3}$ & $96 \mathrm{~h}$ \\
\hline \multicolumn{7}{|l|}{ Range } \\
\hline May & 12.0 & 5.11 & 3.74 & 1.86 & 1.68 & 1.11 \\
\hline June & 9.7 & 3.69 & 2.94 & 1.71 & 1.21 & 1.40 \\
\hline July & 9.5 & 3.15 & 2.56 & 1.35 & 1.08 & 0.98 \\
\hline August & 9.3 & 3.08 & 2.10 & 0.91 & 0.91 & 1.62 \\
\hline September & 9.4 & 2.18 & 1.67 & 0.76 & 0.34 & 2.18 \\
\hline \multicolumn{7}{|l|}{ Meadow } \\
\hline May & 13.7 & 7.70 & 5.01 & 1.68 & 1.66 & 0.85 \\
\hline June & 12.2 & 5.57 & 5.05 & 2.00 & 2.29 & 0.93 \\
\hline July & 12.8 & 5.40 & 2.83 & 1.09 & 1.08 & 1.39 \\
\hline August & 12.4 & 3.87 & 2.30 & 1.00 & 0.90 & 1.47 \\
\hline September & 8.4 & 2.54 & 1.63 & 0.76 & 0.28 & 1.33 \\
\hline SEM & & 0.30 & 0.57 & 0.57 & 0.57 & 0.30 \\
\hline
\end{tabular}

${ }^{1}$ The 96 -h values have been subtracted.

${ }^{2}$ Time point equivalent to $75 \%$ of the total mean retention time (TMRT).

${ }^{3}$ Total mean retention time. 
Table 4. Estimated UIP content (\% DM) of upland range and meadow samples using different approaches (Exp. 1) ${ }^{1}$

\begin{tabular}{|c|c|c|c|c|c|c|}
\hline \multirow[b]{2}{*}{ Forage/month } & \multicolumn{3}{|c|}{ Equation $^{1}$} & \multirow[b]{2}{*}{$75 \%$ TMRT $^{5,6}$} & \multirow[b]{2}{*}{$75 \% \mathrm{TMRT}^{7}$} & \multirow[b]{2}{*}{ TMRT $^{8,9}$} \\
\hline & $1 \mathrm{k}_{\mathrm{d}}^{2}$ & $2 \mathrm{k}_{\mathrm{d}}^{3}$ & $\mathrm{k}_{\mathrm{p}} \operatorname{mean}^{4}$ & & & \\
\hline \multicolumn{7}{|l|}{ Range } \\
\hline May & 2.84 & 2.90 & 3.60 & 3.03 & 2.93 & 2.85 \\
\hline June & 3.09 & 3.15 & 3.56 & 3.11 & 3.27 & 2.61 \\
\hline July & 2.31 & 2.36 & 2.75 & 2.33 & 2.42 & 2.06 \\
\hline August & 2.51 & 2.56 & 3.05 & 2.54 & 2.51 & 2.53 \\
\hline September & 2.96 & 2.99 & 3.35 & 2.93 & 3.17 & 2.52 \\
\hline SEM & 0.49 & 0.48 & 0.43 & 0.56 & 0.55 & 0.64 \\
\hline \multicolumn{7}{|l|}{ Meadow } \\
\hline May & 2.46 & 2.65 & 3.72 & 2.53 & 2.48 & 2.51 \\
\hline June & 2.69 & 2.74 & 3.55 & 2.91 & 2.78 & 3.20 \\
\hline July & 2.55 & 2.55 & 3.54 & 2.48 & 2.49 & 2.47 \\
\hline August & 2.47 & 2.47 & 3.19 & 2.47 & 2.45 & 2.37 \\
\hline September & 2.11 & 2.10 & 2.61 & 2.08 & 2.25 & 1.61 \\
\hline SEM & 0.49 & 0.48 & 0.43 & 0.54 & 0.55 & 0.64 \\
\hline
\end{tabular}

${ }^{1}$ Calculation approach $(\mathrm{CA} ; P<0.01)$; $\mathrm{CA} \times$ month $(P=0.36)$; $\mathrm{CA} \times$ forage $(P=0.017)$; $\mathrm{CA} \times$ month $\times$ forage $(P=0.66)$; forage $(P=0.15)$; forage $\times$ month $(P<0.01)$.

${ }^{2}$ Undegradable intake protein $=\left[\left(1-\mathrm{k}_{\mathrm{d}}{ }^{10}\right) * \mathrm{~B} * \mathrm{k}_{\mathrm{p}} /\left(\mathrm{k}_{\mathrm{p}}+\mathrm{k}_{\mathrm{d}}\right)\right]+\mathrm{C}$, in which $\mathrm{k}_{\mathrm{d}}$ is the rate of neutral detergent insoluble CP degradation from 0-h to 75\% TMRT; $\mathrm{B}$ is the initial pool of neutral detergent insoluble CP; $\mathrm{k}_{\mathrm{p}}$ is the rate of passage calculated from IVDMD; and C is the 96-h neutral detergent insoluble CP.

${ }^{3}$ Undegradable intake protein $=\left[\left(1-\mathrm{k}_{\mathrm{d} 1}{ }^{10}\right) * \mathrm{~B} * \mathrm{k}_{\mathrm{p}} /\left(\mathrm{k}_{\mathrm{p}}+\mathrm{k}_{\mathrm{d} 2}\right)\right]+\mathrm{C}$, in which $\mathrm{k}_{\mathrm{d} 1}$ is the rate of neutral detergent insoluble CP degradation from $0-$ to $10-\mathrm{h}$; B is the initial pool of neutral detergent insoluble CP; $\mathrm{k}_{\mathrm{p}}$ is the rate of passage calculated from IVDMD; $\mathrm{k}_{\mathrm{d} 2}$ is the rate of neutral detergent insoluble CP degradation from 10-h to 75\% TMRT; and C is the 96-h neutral detergent insoluble CP.

${ }^{4}$ Undegradable intake protein $=\left[\mathrm{B} * \mathrm{k}_{\mathrm{p}}\left(\mathrm{k}_{\mathrm{p}}+\mathrm{k}_{\mathrm{d}}\right)\right]+\mathrm{C}$, in which $\mathrm{k}_{\mathrm{d}}$ is the rate of neutral detergent insoluble CP degradation from 0-h to 75\% TMRT; $\mathrm{B}$ is the initial pool of neutral detergent insoluble CP; $\mathrm{k}_{\mathrm{p}}$ is the mean rate of passage of all samples; and $\mathrm{C}$ is the 96 -h neutral detergent insoluble $\mathrm{CP}$.

${ }^{5}$ Time point equivalent to $75 \%$ of the total mean retention time.

${ }^{6}$ Regression equation: $75 \%$ TMRT $=1.11 \mathrm{x}-0.27\left(\mathrm{R}^{2}=0.95\right)$, where $\mathrm{x}$ equals values using $1 \mathrm{k}_{\mathrm{d}}$.

${ }^{7}$ Adjusted to the predicted incubation time point.

${ }^{8}$ Total mean retention time.

${ }^{9}$ Regression equation: TMRT $=1.06 \mathrm{x}-0.30\left(R^{2}=0.54\right)$, where $\mathrm{x}$ equals values using $1 \mathrm{k}_{\mathrm{d}}$.

(Nutt.) Wood], indiangrass (Sorgastrum nutans L. Nash), and grass-like plants (Carex spp. and Cyperus spp.). Dominant species in the subirrigated meadow were: Kentucky bluegrass (Poa pratensis L.), slender wheatgrass [Elymus trachycaulum (Link) Gould ex Shinn.], smooth bromegrass (Bromus inermis Leyss.), timothy (Phleum pratense L.), reed canarygrass (Phalaris arundinacea L.), redtop (Agrostis stolonifera L.), and several species of sedges (Carex spp.) and clover (Trifolium spp.).

Four forage types were included in Exp. 2: alfalfa (Medicago sativa L.), birdsfoot trefoil (Lotus corniculatus L.), kura clover (Trifolium ambiguum M. Bieb.), and smooth bromegrass (Bromus inermis Leyss.). Masticate samples were previously collected from smooth bromegrass pastures fertilized with $56 \mathrm{~kg}$ of $\mathrm{N} / \mathrm{ha}$ or interseeded with birdsfoot trefoil, alfalfa, or kura clover (Ullerich, 2001) at the University of Nebraska Research and Development Center, Ithaca, Nebraska. Diet samples were collected using 4 ruminally fistulated steers (358 kg) grazing fertilized smooth bromegrass, alfalfa and smooth bromegrass, birdsfoot trefoil and smooth bromegrass, or kura clover and smooth bromegrass. Two samples were composited to represent the midpoint of a grazing period. There were 4 periods (May through September) in which diet samples were col- lected. The clipped samples from one collection period (May) were composed of only each single forage: smooth bromegrass, alfalfa, birdsfoot trefoil, or kura clover. All masticate (diet) and clipped samples were freeze-dried and ground to pass through a 2-mm screen for in situ incubation. A subsample was ground through a $1-\mathrm{mm}$ screen for laboratory analysis.

\section{In Situ Procedure}

Two ruminally cannulated British-breed crossbred steers $(556 \mathrm{~kg})$, housed in individual stalls, were used to incubate samples in both experiments and for IVDMD analysis. The basal diet consisted of $70 \%$ smooth bromegrass hay and $30 \%$ concentrate fed twice daily for a total intake of $1.5 \%$ of BW. In vitro dry matter disappearance of the forage samples (1-mm grind) was determined using the Tilley and Terry method (1963) modified by the addition of $1 \mathrm{~g} / \mathrm{L}$ of urea to the McDougall's buffer (Weiss, 1994). Incubation time points equivalent to the TMRT and 75\% TMRT were estimated using IVDMD to estimate the rate of passage. Two different equations were used to estimate the rate of passage due to information available relating IVDMD to rate of passage at the time of each experiment. In Exp. 1, the following equation was used to estimate the rate of 
Table 5. In vitro dry matter digestibilities, rates of passage, mean retention times, and in situ incubation times of clipped and diet samples (Exp. 2)

\begin{tabular}{lcccc}
\hline \hline Forage/month & IVDMD & $\mathrm{k}_{\mathrm{p}}{ }^{1} \% / \mathrm{h}$ & $75 \% \mathrm{TMRT}^{2}$ & Incubation, $^{3} \mathrm{~h}$ \\
\hline Clipped $^{4}$ & & & & \\
Alf & 68.6 & 4.98 & 22.6 & 23.2 \\
BFT & 79.5 & 6.29 & 19.4 & 20.7 \\
Kura & 82.9 & 6.70 & 18.7 & 20.7 \\
Brome & 64.2 & 4.46 & 24.3 & 23.2 \\
Diet $^{5}$ & & & & \\
Alf 1 & 65.5 & 4.61 & 23.8 & 23.2 \\
Alf 2 & 64.4 & 4.48 & 24.2 & 23.2 \\
Alf 3 & 57.5 & 3.64 & 28.1 & 29.3 \\
Alf 4 & 54.9 & 3.34 & 30.0 & 29.3 \\
BFT 1 & 68.8 & 5.01 & 22.5 & 23.2 \\
BFT 2 & 63.8 & 4.41 & 24.5 & 23.2 \\
BFT 3 & 67.3 & 4.82 & 23.1 & 23.2 \\
BFT 4 & 54.4 & 3.28 & 30.4 & 29.3 \\
Kura 1 & 76.3 & 5.91 & 20.2 & 20.7 \\
Kura 2 & 71.2 & 5.29 & 21.7 & 20.7 \\
Kura 3 & 73.3 & 5.55 & 21.0 & 20.7 \\
Kura 4 & 59.6 & 3.90 & 26.7 & 26.4 \\
Brome 1 & 68.4 & 4.95 & 22.6 & 23.2 \\
Brome 2 & 63.8 & 4.40 & 24.5 & 23.2 \\
Brome 3 & 60.9 & 4.06 & 26.0 & 26.4 \\
Brome 4 & 53.8 & 3.2 & 30.9 & 29.3 \\
SEM & 0.74 & & & \\
\hline
\end{tabular}

${ }^{1}$ Rate of passage $=0.12($ IVDMD $\%)-3.25$.

${ }^{2} 75 \%$ TMRT $=\left[\left(1 \div \mathrm{k}_{\mathrm{p}}\right)+10\right] * 0.75$.

${ }^{3}$ Actual incubation time.

${ }^{4}$ Alfalfa (Alf), birdsfoot trefoil (BFT), kura clover (Kura), and smooth brome (Brome) samples collected by clipping or animal selection (diet) over 4 periods.

${ }^{5}$ Diet samples collected May through September.

passage: $\mathrm{k}_{\mathrm{p}}(\% / \mathrm{h})=0.07(\mathrm{IVDMD}, \%)-0.20$ (Klopfenstein et al., 2001). In Exp. 2, the following equation was used: $\mathrm{k}_{\mathrm{p}}(\% / \mathrm{h})=0.12(\mathrm{IVDMD}, \%)-3.25$ (Klopfenstein et al., 2000).

The inverse of the rate of passage $\left(\mathrm{k}_{\mathrm{p}}\right)$ was used to determine MRT, and a 10-h passage lag was added to the estimated MRT to yield the TMRT. The estimated TMRT for forages in Exp. 1 collected from range and meadow in May and meadow in June was approximately $31 \mathrm{~h}$. Range samples in June and all range and meadow samples in July and August had TMRT of approximately $35 \mathrm{~h}$, while the estimated TMRT for range and meadow samples collected in September was $40 \mathrm{~h}$. Incubation time points for the forages in Exp. 2, based on rates of passage (TMRT and 75\% TMRT), ranged from 18.7 to $41.2 \mathrm{~h}$; therefore, samples were grouped into incubation time points based on their respective 75\% TMRT and TMRT.

Dacron bags $(5 \times 10 \mathrm{~cm}$; Ankom Inc., Fairport, NY) with an average pore size of $50 \mu \mathrm{M}$ were filled with 1.25 $\mathrm{g}$ of air-dry forage (2-mm grind) to yield an approximate sample DM:surface area ratio of $12.5 \mathrm{mg} \mathrm{DM}: \mathrm{cm}^{2}$. In situ incubations were replicated using duplicate bags (Exp. 1) and using one bag per sample at each time point over $2 \mathrm{~d}$ (Exp. 2). This provided 2 bags/steer and 4 total bags/forage (2 bags/forage at $96 \mathrm{~h}$ ). Incubations included 10-h, 75\% TMRT, TMRT, and 96-h time points.
Four nonincubated (0-h) bags were also prepared for each sample. Bags were placed in mesh bags $(40 \times 36$ $\mathrm{cm}$ ) at a maximum rate of 50 in situ bags per mesh bag, presoaked in $39^{\circ} \mathrm{C}$ tap water for $0.3 \mathrm{~h}$, and incubated in the ventral rumen of 2 ruminally fistulated steers (maximum of 6 mesh bags/steer). Samples were incubated in reverse order for $96 \mathrm{~h}$, TMRT, 75\% TMRT, and $10 \mathrm{~h}$, and removed simultaneously.

Bags were machine washed $\left(39^{\circ} \mathrm{C}\right)$ after removal from the rumen for 5 rinse cycles consisting of a 1-min agitation and a 2-min spin. Bags were then bulk refluxed in neutral detergent solution using a fiber analyzer (Ankom Inc., Fairport, NY) to remove microbial contamination according to the procedure of Mass et al. (1999) and dried at $60^{\circ} \mathrm{C}$ for $48 \mathrm{~h}$. Samples were air-equilibrated for $3 \mathrm{~h}$ before weighing, and residues were analyzed for $\mathrm{N}$ by the combustion method (AOAC, 1996) using a combustion N analyzer (Leco FP-528; St. Joseph, MI).

\section{Calculations}

Undegradable intake protein (\% DM) was calculated using the following equation of Broderick (1994), modified to include a 10-h passage lag: UIP $(\% \mathrm{DM})=$ $\left\{\left[\left(1-\mathrm{k}_{\mathrm{d}}{ }^{10}\right) * \mathrm{~B} *\left(\mathrm{k}_{\mathrm{p}} /\left(\mathrm{k}_{\mathrm{p}}+\mathrm{k}_{\mathrm{d}}\right)\right]+\mathrm{C}\right\} * 6.25\right.$, in which fraction $B$ is the original $(0-h)$ NDIN minus the 96 -h NDIN, fraction $\mathrm{C}$ is the $96-\mathrm{h}$ NDIN, $\mathrm{k}_{\mathrm{p}}$ is rate of passage, and $\mathrm{k}_{\mathrm{d}}$ is rate of digestion. For time points equivalent to TMRT and 75\% TMRT, UIP (\% DM) was calculated as: NDIN *6.25/DM, in which NDIN represented that remaining after incubation and DM represented the original sample DM. Neutral detergent insoluble $\mathrm{N}$ was measured on each in situ residue as well as on the original sample allowing for the construction of a degradation curve for NDIN. The original (0-h) NDIN minus the 96-h NDIN represented the potentially degradable (B) fraction of NDIN. A first-order disappearance model was used to calculate the rates of ruminal degradation $\left(\mathrm{k}_{\mathrm{d}}, \% / \mathrm{h}\right)$ for each in situ CP fraction. The natural logarithm of the percentage of potentially degradable NDIN remaining (corrected for the 96-h undegradable fraction) was regressed against time to calculate the $k_{d}$ (slope of the regression line). The following equation was used: $\mathrm{k}_{\mathrm{d}}(\% / \mathrm{h})=[\ln (\%$ of $\mathrm{B}$ remaining at $\mathrm{X})-\ln$ (\% of $\mathrm{B}$ remaining at $\mathrm{Y})] /(\mathrm{x}-\mathrm{y})$, in which $\mathrm{X}$ and $\mathrm{Y}$ are any 2 time points in hours.

Samples in Exp. 1 were analyzed using the MIXED procedure of SAS. Fixed effects in the model included forage (meadow and range) and incubation time $(10 \mathrm{~h}$, 75\% TMRT, and TMRT). Pasture, nested within forage type, was included as a random effect. Month of collection was a repeated measure (compound symmetry covariance structure), and steer in which samples were incubated $(n=2)$ was considered a random effect. Masticate samples in Exp. 2 were analyzed using the repeated measures structure of the MIXED procedure of SAS. Fixed effects in the model for the diet samples included: forage (alfalfa, birdsfoot trefoil, kura clover, and smooth bromegrass), incubation time (10 h, 75\% TMRT, and 
Table 6. Original CP and potentially degradable neutral detergent insoluble CP (\% DM) remaining of clipped and diet samples (Exp. 2)

\begin{tabular}{|c|c|c|c|c|c|c|}
\hline \multirow[b]{2}{*}{ Sample } & \multirow{2}{*}{$\begin{array}{l}\text { Original } \\
\text { CP }\end{array}$} & \multicolumn{5}{|c|}{ Incubation time } \\
\hline & & $0 \mathrm{~h}^{1}$ & $10 \mathrm{~h}^{1}$ & $75 \%$ TMRT $^{1}$ & TMRT $^{1}$ & $96 \mathrm{~h}$ \\
\hline \multicolumn{7}{|l|}{ Clipped $^{2}$} \\
\hline Alf & 13.4 & 2.50 & 0.99 & 0.35 & 0.20 & 1.25 \\
\hline BFT & 15.0 & 2.74 & 1.19 & 0.54 & 0.37 & 1.48 \\
\hline Kura & 22.6 & 2.23 & 0.68 & 0.24 & 0.10 & 0.64 \\
\hline Brome & 13.2 & 4.18 & 2.15 & 0.66 & 0.33 & 1.01 \\
\hline SEM & & 0.08 & 0.11 & 0.11 & 0.11 & 0.08 \\
\hline \multicolumn{7}{|l|}{$\operatorname{Diet}^{3}$} \\
\hline Alf 1 & 16.3 & 6.22 & 2.59 & 0.69 & 0.41 & 0.92 \\
\hline Alf 2 & 16.1 & 2.88 & 1.74 & 0.33 & 0.10 & 1.17 \\
\hline Alf 3 & 12.3 & 3.25 & 1.40 & 0.29 & 0.04 & 1.39 \\
\hline Alf 4 & 11.5 & 2.97 & 1.45 & 0.55 & 0.17 & 1.46 \\
\hline BFT 1 & 17.6 & 3.50 & 1.87 & 0.77 & 0.35 & 0.85 \\
\hline BFT 2 & 17.0 & 4.37 & 1.61 & 0.81 & 0.42 & 0.89 \\
\hline BFT 3 & 15.0 & 3.61 & 1.48 & 0.39 & 0.36 & 0.94 \\
\hline BFT 4 & 13.0 & 2.90 & 1.55 & 0.44 & 0.09 & 1.51 \\
\hline Kura 1 & 18.2 & 3.72 & 0.68 & 0.22 & 0.05 & 0.65 \\
\hline Kura 2 & 16.5 & 3.71 & 1.83 & 0.22 & 0.33 & 0.91 \\
\hline Kura 3 & 19.0 & 3.06 & 1.06 & 0.46 & 0.41 & 0.75 \\
\hline Kura 4 & 17.2 & 3.84 & 1.46 & 0.48 & 0.40 & 1.19 \\
\hline Brome 1 & 12.3 & 2.63 & 1.57 & 0.47 & 0.38 & 0.65 \\
\hline Brome 2 & 12.5 & 5.36 & 2.00 & 0.59 & 0.27 & 0.88 \\
\hline Brome 3 & 11.7 & 4.01 & 1.75 & 0.75 & 0.45 & 1.19 \\
\hline Brome 4 & 8.90 & 2.36 & 1.19 & 0.37 & 0.19 & 1.33 \\
\hline SEM & & 0.14 & 0.07 & 0.07 & 0.08 & 0.12 \\
\hline
\end{tabular}

${ }^{1}$ The $96-\mathrm{h}$ values have been subtracted, total mean retention time (TMRT).

${ }^{2}$ Clipped samples collected in May; alfalfa (Alf), birdsfoot trefoil (BFT), Kura clover (Kura), and smooth brome (Brome).

${ }^{3}$ Diet samples collected May through September.

TMRT), and time (May, July, August, and September) as the repeated measure. Steer in which samples were incubated $(\mathrm{n}=2)$ and day were included as random effects. Clipped samples in Exp. 2 were analyzed with forage (alfalfa, birdsfoot trefoil, kura clover, and smooth bromegrass) and incubation time (10 h, 75\% TMRT, and TMRT) as fixed effects and steer and day as random effects.

\section{RESULTS AND DISCUSSION}

The IVDMD values for upland range and meadow samples collected from May through September (Exp. 1) are shown in Table 1 . From the IVDMD values, rates of passage and MRT were calculated and actual incubation times are shown. The original $\mathrm{CP}$ and undegraded protein (\% DM) values are shown in Table 2 . Neutral detergent insoluble $\mathrm{CP}$ values $(\% \mathrm{DM})$ remaining at 0 , 10, 75\% TMRT, and TMRT were corrected for the 96$\mathrm{h}$ fraction. Rates of degradation from 0 to $10 \mathrm{~h}, 10 \mathrm{~h}$ to 75\% TMRT, and from 75\% TMRT to TMRT for upland range and meadow samples collected May through September are shown in Table 3. There was a month $\times$ incubation time interaction $(P<0.05)$ for rates of neutral detergent insoluble CP degradation from 0 to $10 \mathrm{~h}$ and $10 \mathrm{~h}$ to $75 \%$ TMRT. Rates of neutral detergent insoluble CP degradation of upland range and meadow samples were slower $(P<0.05)$ during the first $10 \mathrm{~h}$ of incubation in May and June compared to rates from 10 $\mathrm{h}$ to $75 \%$ TMRT, but rates of degradation were not different ( $P=0.34$ to 0.71$)$ for the rest of the collection periods. There was also a tendency $(P=0.09)$ for a month $\times$ forage interaction for the rate of neutral detergent insoluble CP degradation as meadow samples in May and July degraded more rapidly from 0 to $75 \%$ TMRT than range samples $(P<0.05)$.

The UIP values obtained at 75\% TMRT and TMRT and calculated using fractional rates of passage and degradation are shown in Table 4 for diet samples in Exp. 1. The single in situ UIP estimates (75\% TMRT and TMRT) were compared with values of UIP obtained using a standard equation (Broderick, 1994) modified to include a 10 -h passage lag. Undegradable intake protein values obtained with competing $\mathrm{k}_{\mathrm{p}}$ and $\mathrm{k}_{\mathrm{d}}$ (equation) represent mechanisms in the rumen and may be the most accurate estimates; therefore, $75 \%$ TMRT and TMRT UIP values were regressed against the calculated UIP values. Undegradable intake protein at $75 \%$ TMRT was more highly correlated $\left(R^{2}=0.95\right)$ to calculated values than UIP at TMRT $\left(R^{2}=0.54\right)$. The slope of the regression was 1.11 and was not different from 1 $(P=0.17)$. The intercept was -0.27 and was not different from $0(P=0.32)$.

The most widely used equation for calculating UIP (Broderick, 1994) does not include a passage lag and assumes a single rate of passage for all samples. There- 
Table 7. Rate of degradation $(\% / \mathrm{h})$ of neutral detergent insoluble $\mathrm{CP}$ of clipped and diet samples from 0 to $10 \mathrm{~h}$, $10 \mathrm{~h}$ to $75 \%$ total mean retention time (TMRT), and $75 \%$ TMRT to TMRT (Exp. 2)

\begin{tabular}{|c|c|c|c|}
\hline Sample & 0 to 10 & $\begin{array}{c}10 \text { to } 75 \% \\
\text { TMRT }\end{array}$ & $\begin{array}{l}75 \% \text { TMRT } \\
\text { to TMRT }\end{array}$ \\
\hline \multicolumn{4}{|l|}{ Clipped $^{1}$} \\
\hline Alf & 9.41 & 8.05 & 5.29 \\
\hline BFT & 8.85 & 8.21 & 3.61 \\
\hline Kura & 13.91 & 12.05 & 13.38 \\
\hline Brome & 6.70 & 9.45 & 6.32 \\
\hline SEM & 2.16 & 3.89 & 4.49 \\
\hline \multicolumn{4}{|l|}{$\operatorname{Diet}^{2}$} \\
\hline Alf 1 & 9.62 & 11.64 & 3.67 \\
\hline Alf 2 & 5.85 & 11.12 & 10.28 \\
\hline Alf 3 & 8.43 & 4.02 & 22.80 \\
\hline Alf 4 & 7.34 & 5.38 & 5.49 \\
\hline BFT 1 & 7.54 & 7.86 & 7.51 \\
\hline BFT 2 & 10.33 & 7.80 & 6.67 \\
\hline BFT 3 & 9.62 & 9.58 & 8.59 \\
\hline BFT 4 & 6.94 & 6.40 & 7.10 \\
\hline Kura 1 & 17.11 & 22.64 & 5.03 \\
\hline Kura 2 & 7.34 & 16.47 & 5.19 \\
\hline Kura 3 & 10.92 & 7.94 & 5.13 \\
\hline Kura 4 & 9.91 & 11.53 & 9.48 \\
\hline Brome 1 & 5.22 & 10.40 & 6.65 \\
\hline Brome 2 & 9.92 & 9.56 & 9.34 \\
\hline Brome 3 & 8.38 & 5.16 & 9.23 \\
\hline Brome 4 & 6.86 & 7.97 & 8.96 \\
\hline SEM & 1.13 & 2.19 & 2.61 \\
\hline
\end{tabular}

${ }^{1}$ Clipped samples collected in May; alfalfa (Alf), birdsfoot trefoil (BFT), Kura clover (Kura), and smooth brome (Brome).

${ }^{2}$ Diet samples collected May through September.

fore, UIP values were calculated without using a passage lag and using the same rate of passage for all samples (mean kp of all samples; Table 1). The UIP values using this standard method were $32 \%$ greater $(P<0.01)$ than those calculated with one rate of degradation, a 10-h lag, and individual rates of passage. The calculation of 2 rates of degradation ( 0 to $10 \mathrm{~h}$ and 10 $\mathrm{h}$ to $75 \%$ TMRT) represents 2 possible approaches to calculating UIP values using the standard equation; therefore, equation UIP values (\% DM) were calculated using a constant rate of degradation from 0 to $75 \%$ TMRT and using 2 different rates of degradation from 0 to $10 \mathrm{~h}$ and $10 \mathrm{~h}$ to $75 \%$ TMRT. The use of 2 rates in the equation did not $(P=0.52)$ change the overall UIP value (Table 4). Despite the differences that may exist in the rates of protein degradation over the course of incubation, the use of a constant rate of degradation from 0 to $75 \%$ TMRT seems to be a viable option in the determination of the UIP content in forages.

Samples included in the in situ analysis were grouped into incubation time points so that an actual incubation time point of $20 \mathrm{~h}$ would include samples with estimated $75 \%$ TMRT points of 19,20 , and $21 \mathrm{~h}$. The $75 \%$ TMRT values were adjusted to their predicted incubation time point using the following equation: UIP $(\% \mathrm{DM})=$ Fraction $\mathrm{B} *\left(1-\mathrm{k}_{\mathrm{d}}\right)^{\mathrm{h}}$, in which $\mathrm{h}=$ predicted incubation actual incubation (h) and Fraction B is the UIP mea- sured at $75 \%$ TMRT corrected for the 96 -h fraction. The rate of degradation from $10 \mathrm{~h}$ to $75 \%$ TMRT was used in the calculation if the predicted incubation time was less than the actual time incubated, and the rate of degradation from $75 \%$ TMRT to TMRT was used if the predicted incubation time was longer than the actual time incubated. Adjusted 75\% TMRT values were simi$\operatorname{lar}(P=0.63)$ to unadjusted UIP values at $75 \%$ TMRT (Table 4).

The IVDMD values for diet and clipped samples in Exp. 2 are shown in Table 5. The rates of passage and mean retention times were calculated from IVDMD. Actual incubation times are shown in Table 5. The original $\mathrm{CP}$ and potentially degradable neutral detergent insoluble $\mathrm{CP}(\% \mathrm{DM})$ remaining at each incubation time point of diet and clipped samples in Exp. 2 are shown in Table 6. These values were used in the calculation of the rates of NDIN degradation. There were no interactions or main effects $(P=0.11$ to 0.71$)$ for the rate of NDIN degradation of diet or clipped samples (Table 7). Rates of degradation were not different for forages within diet samples from 0 to $10 \mathrm{~h}$ and $10 \mathrm{~h}$ to $75 \%$ TMRT ( $P=0.82$ ) or from $10 \mathrm{~h}$ to $75 \%$ TMRT and $75 \%$ TMRT to TMRT $(P=0.87)$. Rates of degradation were not different among forages within clipped samples from 0 to $10 \mathrm{~h}$ and $10 \mathrm{~h}$ to $75 \%$ TMRT $(P=0.86)$ nor from $10 \mathrm{~h}$ to $75 \%$ TMRT and 75\% TMRT and TMRT $(P=0.44)$, suggesting a constant rate of degradation for these forages from $0 \mathrm{~h}$ to TMRT. The rate of degradation from $0 \mathrm{~h}$ to $75 \% \mathrm{TMRT}$ was not different among forages in $\operatorname{diet}(P=0.12)$ or clipped $(P=0.11)$ samples.

Undegradable intake protein (\% DM) values for the diet and clipped samples in Exp. 2 are shown in Table 8. Estimates of UIP from $75 \%$ TMRT incubations were more highly correlated $\left(\mathrm{R}^{2}=0.98\right)$ with those calculated from the equation using fractional rates of degradation and passage plus accounting for a passage lag than estimates of UIP from TMRT incubations $\left(\mathrm{R}^{2}=0.83\right)$. The relationship observed was consistent with the single incubation UIP estimates for diet samples from upland range and meadow pastures at 75\% TMRT when compared with the equation values for UIP in Exp. 1. The slope of the regression of the 75\% TMRT UIP values on equation values was not different from $1(P=0.99)$, and the intercept was not different from $0(P=0.11)$. The UIP values (\% DM) at $75 \%$ TMRT were also adjusted to their exact length of incubation predicted by the 75\% TMRT point as in Exp. 1; however, adjusted 75\% TMRT values were not different from unadjusted $75 \%$ TMRT UIP values for $\operatorname{diet}(P=0.76)$ or clipped $(P=0.84)$ samples. The UIP values calculated using the standard procedure (no passage lag and one passage rate) were $45 \%$ greater $(P<0.001)$ than values using a rate of degradation, a $10-\mathrm{h}$ lag, and individual rates of passage.

There were main effects $(P<0.05)$ of calculation approach and forage for the 4 clipped samples on estimated UIP. Undegradable intake protein (\% DM) values of the clipped samples based on TMRT (1.26) were 
Table 8. Estimated UIP content (\% DM) of clipped and diet samples using different approaches (Exp. 2)

\begin{tabular}{|c|c|c|c|c|c|c|}
\hline \multirow[b]{2}{*}{ Sample } & \multicolumn{3}{|c|}{ Equation } & \multirow[b]{2}{*}{$75 \% \mathrm{TMRT}^{4,5}$} & \multirow[b]{2}{*}{$75 \%$ TMRT $^{6}$} & \multirow[b]{2}{*}{ TMRT $^{4}$, } \\
\hline & $1 \mathrm{k}_{\mathrm{d}}{ }^{1}$ & $2 \mathrm{k}_{\mathrm{d}}^{2}$ & $\mathrm{k}_{\mathrm{p}}$ mean $^{3}$ & & & \\
\hline \multicolumn{7}{|l|}{ Clipped $^{8}$} \\
\hline Alf & 1.62 & 1.61 & 2.22 & 1.59 & 1.60 & 1.45 \\
\hline $\mathrm{BFT}$ & 2.01 & 2.01 & 2.60 & 2.01 & 2.07 & 1.85 \\
\hline Kura & 0.90 & 0.90 & 1.36 & 0.88 & 0.97 & 0.58 \\
\hline Brome & 1.66 & 1.71 & 2.72 & 1.67 & 1.61 & 1.19 \\
\hline SEM & 0.10 & 0.09 & 0.10 & 0.11 & 0.14 & 0.13 \\
\hline \multicolumn{7}{|l|}{$\operatorname{Diet}^{9}$} \\
\hline Alf 1 & 1.65 & 1.70 & 2.83 & 1.61 & 1.58 & 1.33 \\
\hline Alf 2 & 1.55 & 1.63 & 2.06 & 1.51 & 1.49 & 1.51 \\
\hline Alf 3 & 2.13 & 2.03 & 2.83 & 1.72 & 1.85 & 1.43 \\
\hline Alf 4 & 2.06 & 2.03 & 2.75 & 2.01 & 2.00 & 1.63 \\
\hline BFT 1 & 1.52 & 1.62 & 2.16 & 1.62 & 1.66 & 1.20 \\
\hline BFT 2 & 1.66 & 1.66 & 2.52 & 1.70 & 1.65 & 1.31 \\
\hline BFT 3 & 1.38 & 1.40 & 2.08 & 1.33 & 1.35 & 1.30 \\
\hline BFT 4 & 2.05 & 2.05 & 2.73 & 1.95 & 1.93 & 1.60 \\
\hline Kura 1 & 1.06 & 1.11 & 1.61 & 0.95 & 1.18 & 0.71 \\
\hline Kura 2 & 1.21 & 1.35 & 1.87 & 1.13 & 1.23 & 1.20 \\
\hline Kura 3 & 1.20 & 1.17 & 1.74 & 1.21 & 1.20 & 1.16 \\
\hline Kura 4 & 1.75 & 1.72 & 2.51 & 1.68 & 1.69 & 1.59 \\
\hline Brome 1 & 1.13 & 1.19 & 1.62 & 1.12 & 1.13 & 1.03 \\
\hline Brome 2 & 1.50 & 1.50 & 2.57 & 1.47 & 1.40 & 1.15 \\
\hline Brome 3 & 1.99 & 1.93 & 2.83 & 1.93 & 1.97 & 1.63 \\
\hline Brome 4 & 1.68 & 1.70 & 2.23 & 1.70 & 1.66 & 1.52 \\
\hline SEM & 0.07 & 0.07 & 0.08 & 0.09 & 0.11 & 0.09 \\
\hline
\end{tabular}

${ }^{1}$ Undegradable intake protein $=\left(1-\mathrm{k}_{\mathrm{d}}{ }^{10}\right) * \mathrm{~B} * \mathrm{k}_{\mathrm{p}} /\left(\mathrm{k}_{\mathrm{p}}+\mathrm{k}_{\mathrm{d}}\right)+\mathrm{C}$, in which $\mathrm{k}_{\mathrm{d}}$ is the rate of neutral detergent insoluble CP degradation from 0-h to 75\% TMRT; B is the initial pool of neutral detergent insoluble CP; $\mathrm{k}_{\mathrm{p}}$ is the rate of passage calculated from IVDMD; and C is the 96-h neutral detergent insoluble CP.

${ }^{2}$ Undegradable intake protein $=\left[\left(1-\mathrm{k}_{\mathrm{d} 1}{ }^{10}\right) * \mathrm{~B} * \mathrm{k}_{\mathrm{p}} /\left(\mathrm{k}_{\mathrm{p}}+\mathrm{k}_{\mathrm{d} 2}\right)\right]+\mathrm{C}$, in which $\mathrm{k}_{\mathrm{d} 1}$ is the rate of neutral detergent insoluble CP degradation from 0 to $10-\mathrm{h}$; B is the initial pool of neutral detergent insoluble CP; $\mathrm{k}_{\mathrm{p}}$ is the rate of passage calculated from IVDMD; $\mathrm{k}_{\mathrm{d} 2}$ is the rate of neutral detergent insoluble CP degradation from $10-\mathrm{h}$ to $75 \%$ TMRT; and $\mathrm{C}$ is the $96-\mathrm{h}$ neutral detergent insoluble CP.

${ }^{3}$ Undegradable intake protein $=\left[\mathrm{B} * \mathrm{k}_{\mathrm{p}} /\left(\mathrm{k}_{\mathrm{p}}+\mathrm{k}_{\mathrm{d}}\right)\right]+\mathrm{C}$, in which $\mathrm{k}_{\mathrm{d}}$ is the rate of neutral detergent insoluble CP degradation from 0-h to 75\% TMRT; $\mathrm{B}$ is the initial pool of neutral detergent insoluble CP; $\mathrm{k}_{\mathrm{p}}$ is the mean rate of passage of all samples; and $\mathrm{C}$ is the 96 -h neutral detergent insoluble $\mathrm{CP}$.

${ }^{4}$ In situ incubation at $75 \%$ TMRT and TMRT (total mean retention time).

${ }^{5}$ Regression equation: $75 \%$ TMRT $=1.00 \mathrm{x}+0.02\left(\mathrm{R}^{2}=0.98\right)$, in which $\mathrm{x}$ equals values using $1 \mathrm{k}_{\mathrm{d}}$.

${ }^{6}$ Adjusted to predicted incubation time.

${ }^{7}$ Regression equation: TMRT $=0.92 \mathrm{x}-0.09\left(\mathrm{R}^{2}=0.83\right)$ where $\mathrm{x}$ equals values using $1 \mathrm{k}_{\mathrm{d}}$.

${ }^{8}$ Clipped samples collected in May; alfalfa (Alf), birdsfoot trefoil (BFT), kura clover (Kura), smooth brome (Brome); calculation approach $(\mathrm{CA} ; P<0.01)$; forage $(P<0.01)$; $\mathrm{CA} \times$ forage $(P=0.18)$.

${ }^{9}$ Diet samples collected May through September; CA $(P<0.01)$; period $(P<0.01)$; CA $\times$ period $(P=0.99$; forage $(P<0.01)$; CA $\times$ forage $(P=0.73)$; forage $\times$ period $(P<0.01)$; CA $\times$ period $\times$ forage $(P=0.77)$.

lower $(P<0.01)$ than when they were estimated from $75 \%$ TMRT (1.54), and degradation was overestimated when samples were incubated for their TMRT. Undegradable intake protein values (\% DM) for birdsfoot trefoil, smooth bromegrass, alfalfa, and kura clover using adjusted $75 \%$ TMRT were $2.07,1.61,1.60$, and 0.94 , respectively. Birdsfoot trefoil (clip) had the highest ( $P$ $<0.01)$ UIP (\% DM), whereas kura clover was lowest in UIP. Clipped alfalfa and smooth bromegrass were intermediate in UIP content.

There was an effect $(P<0.01)$ of calculation approach on diet UIP values (Table 8). There was an interaction of calculation approach and period $(P<0.01)$ but no interaction of calculation approach $\times$ forage $(P=0.73)$ or 3-way interaction of calculation method, period, and forage $(P=0.77)$. There was a forage $\times$ period (sampling month) interaction $(P<0.01)$ for UIP of the diet samples
(Table 8). The UIP (\% DM) of alfalfa and birdsfoot trefoil diet samples in May and September was not different; however, kura clover and smooth bromegrass diet samples were greater in UIP in September than in May.

Hoffman et al. (1993) measured UIP of alfalfa, birdsfoot trefoil, and smooth bromegrass clipped samples across 3 maturities. Alfalfa contained 4.33, 4.61, and $4.88 \%$ UIP (\% DM) at maturity 1,2 , and 3 , respectively. Birdsfoot trefoil contained 3.48, 3.56, and $4.23 \%$ UIP $(\% \mathrm{DM})$ and smooth bromegrass was $4.68,4.62$, and $5.59 \%$ UIP (\% DM) at maturity 1,2 , and 3 , respectively. The UIP was calculated using the standard equation outlined by Broderick (1994) and a correction for microbial $\mathrm{N}$ was made. The reported values for these forages were greater than the UIP values in the current study likely due to the size of the measured B fraction of protein and/or oven drying of samples. The size of frac- 


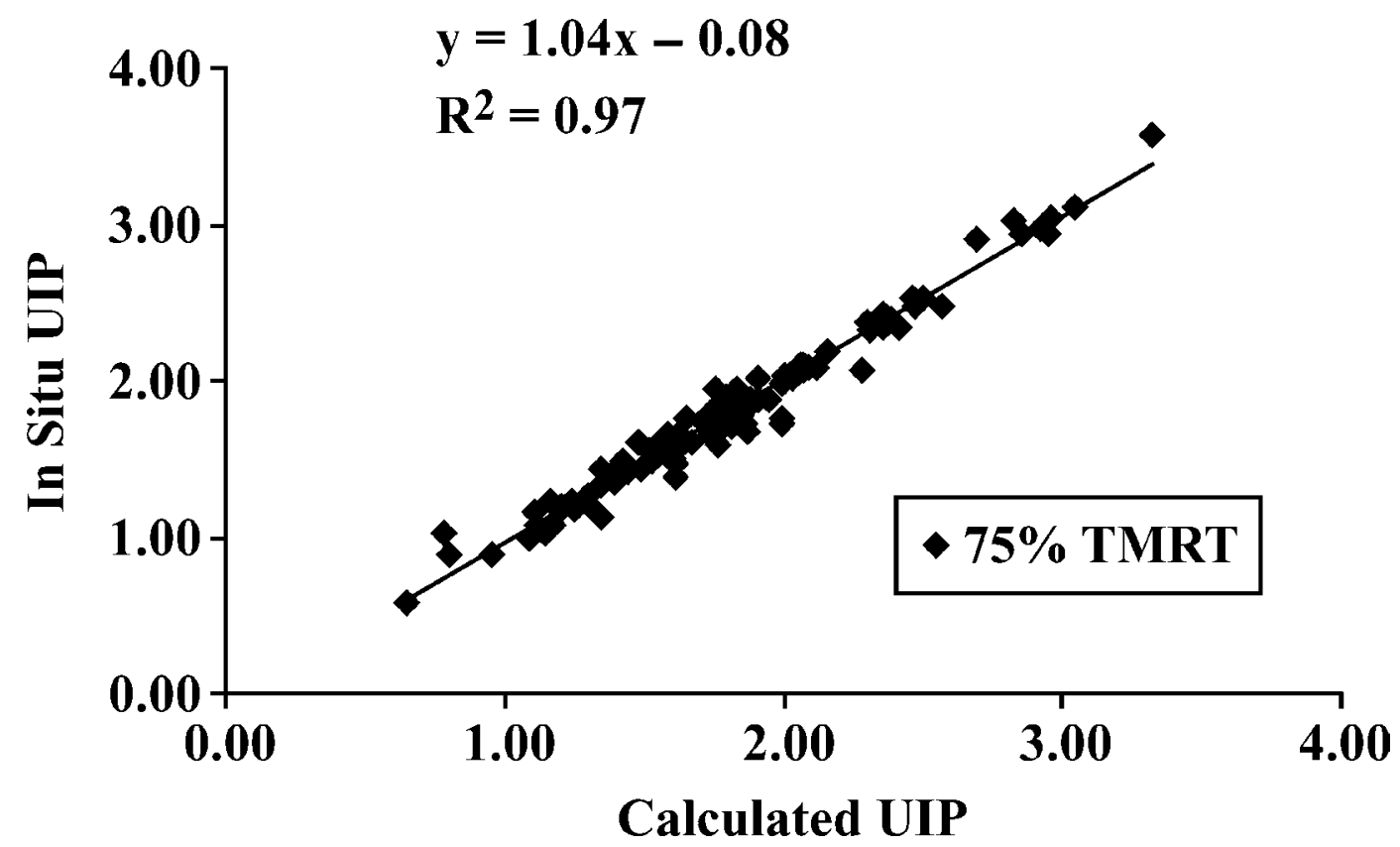

Figure 1. Comparison of undegradable intake protein values (UIP, \% DM) at 75\% total mean retention time (TMRT) with calculated values using a single rate of degradation.

tion B in the study by Hoffman et al. (1993) was roughly twice that of the B fraction for birdsfoot trefoil, alfalfa, and smooth bromegrass observed in the current study. A rate of passage of $0.06 \mathrm{~h}^{-1}$ was assumed, which would be equivalent to a $16.7 \mathrm{~h} \mathrm{MRT}$. A passage lag was not included and may explain the substantially larger UIP values reported.

In situ incubations of forage residues using the MRT of the particles in the rumen seems logical, as it is the mean time that the forage particles are in the rumen, and it is reflective of the rate of passage of particles through the rumen. A lag in the passage of forage particles from the rumen of $10 \mathrm{~h}$ has been suggested and is a period of time in which forage particles undergo changes increasing their chance of passage (Ellis et al., 1999; Wylie et al., 2000). This additional time that forage particles spend in the rumen is important to account for because degradation of protein may be occurring during this passage lag period, and the flow of the UIP fraction of forages from the rumen may be reduced.

Accounting for a lag in passage by adding $10 \mathrm{~h}$ to the MRT represents the TMRT in which particles may be degraded. Previous attempts in research to select a single time point to mimic the estimated MRT of the feedstuff have inaccurately estimated the degradative properties of the feed (Orskov and McDonald, 1979; Broderick, 1994). The UIP estimates of forages at TMRT incubations may overestimate degradation of protein; the UIP values at TMRT tended to produce smaller UIP estimates than those predicted by the standard equation described by Broderick (1994) with the inclusion of a 10-h passage lag. As a result, the 75\% TMRT time point was tested in the current study in an attempt to more accurately reflect protein degradation in the rumen.

The use of NDIN (Mass et al., 1999) can be used as a direct estimate of UIP in forages at the appropriate incubation time because the microbial $\mathrm{N}$ is effectively removed from the feed residue. The regression of UIP (\% DM) values at 75\% TMRT of forage samples in Exp. 1 and Exp. 2 on equation values using a constant rate of degradation from 0 to $75 \%$ TMRT is shown in Figure 1 . The slope and the intercept of the regression line were not different $(P>0.13)$ from 1 and 0 , respectively. The strong correlation $\left(\mathrm{R}^{2}=0.97\right)$ of the $75 \%$ TMRT and the equation UIP values across a wide range of forages from low quality range samples to high quality legumes indicates that the use of NDIN at 75\% TMRT can be used to accurately quantify the UIP in forages.

Values obtained using the standard procedure (no passage lag and mean rate of passage) were also regressed on values using a constant rate of degradation, a 10-h lag, and individual rates of passage. The slope of the regression equation was not different from one $(P=0.92)$ with an $R^{2}$ of 0.88 ; however, the intercept was different from zero $(P<0.05)$. The values using mean rate of passage were $35 \%$ greater than values using the proposed procedure of 0.75 TMRT. An alternative consideration in the selection of an in situ incubation time point is that of the half-life residency of particles in the rumen (Ellis et al., 1994). The half-life of markers in the rumen is the natural log of a reduction of one-half of the marker concentration divided by the marker's turnover rate. For example, a forage with a rate of passage of $0.05 \mathrm{~h}^{-1}$ would have a MRT of $20 \mathrm{~h}$, a TMRT of $30 \mathrm{~h}$, and the proposed incubation time point of $22.5 \mathrm{~h}$. Using the half-life approach, this forage would 
have a half-life of $13.86 \mathrm{~h}$ (ln 0.5/0.05). The half-life incubation with the inclusion of a 10 -h passage lag would give a proposed incubation time point of $23.86 \mathrm{~h}$, which is close to the 22.5 -h $75 \%$ TMRT point. Additional research may be warranted to further explore this possibility.

\section{IMPLICATIONS}

Incubation time in the rumen and correcting in situ residues for microbial nitrogen are important considerations in the accurate determination of undegradable intake protein in forages. A single in situ incubation time point equivalent to $75 \%$ total mean retention time can be used to determine the undegradable intake protein in forages using neutral detergent solution to correct for microbial nitrogen. A constant rate of degradation can be used in the calculation of undegradable intake protein without changing the overall value even if rates of degradation from 0 to $75 \%$ total mean retention time are not constant. The accurate quantification of the undegradable intake protein fraction in forages is important because undegradable intake protein can be limiting in animals with high metabolizable protein requirements. Improved knowledge of the degradative properties of forages can be incorporated into models using the metabolizable protein system to better predict animal responses.

\section{LITERATURE CITED}

AOAC. 1996. Official Methods of Analysis. 16th ed. Assoc. Off. Anal. Chem., Arlington, VA.

Broderick, G. A. 1994. Quantifying forage protein quality. Pages 200228 in Forage Quality, Evaluation, and Utilization. G. C. Fahey, Jr., ed. American Society of Agronomy, Crop Science Society of America, Soil Science Society of America, Madison, WI.

Ellis, W. C., J. H. Matis, T. M. Hill, and M. R. Murphy. 1994. Methodology for estimating digestion and passage kinetics of forages. Pages 682-756 in Forage Quality, Evaluation, and Utilization. G. C. Fahey, Jr., ed. Am. Soc. Agronomy, Crop Sci. Soc. America, Soil Sci. Soc. America, Madison, WI.
Ellis, W. C., D. P. Poppi, J. H. Matis, H. Lippke, T. M. Hill, and F. M. Rouquette, Jr. 1999. Dietary-digestive-metabolic interactions determining the nutritive potential of ruminant diets. Pages 423-481 in Nutritional Ecology of Herbivores. H. G. Jung and G. C. Fahey, ed. Am. Soc. Anim. Sci., Savoy, IL.

Hoffman, P. C., S. J. Sievert, R. D. Shaver, G. A. Broderick, and T. R. Drendel. 1993. In situ dry matter, protein, and fiber degradation of perennial forages. J. Dairy Sci. 76:2632-2642.

Klopfenstein, T., R. Mass, K. Creighton, and T. Patterson. 2000. Estimating forage protein degradation in the rumen. J. Anim. Sci. 78(Suppl. 1):15. (Abstr.)

Klopfenstein, T. J., R. A. Mass, K. W. Creighton, and H. H. Patterson. 2001. Estimating forage protein degradation in the rumen. J. Anim. Sci. 79(Suppl. 1):208-217.

Mass, R. A., G. P. Lardy, R. J. Grant, and T. J. Klopfenstein. 1999. In situ neutral detergent insoluble nitrogen as a method for measuring forage protein degradability. J. Anim. Sci. 77:1565-1571.

Nocek, J. E. 1985. Evaluation of specific variables affecting in situ estimates of ruminal dry matter and protein digestion. J. Anim. Sci. 60:1347-1358.

Nocek, J. E. 1988. In situ and other methods to estimate ruminal protein and energy digestibility: A review. J. Dairy Sci. 71:2051-2068.

Nocek, J. E., and A. L. Grant. 1987. Characterization of in situ nitrogen and fiber digestion and bacterial nitrogen contamination of hay crop forages preserved at different dry matter percentages. J. Anim. Sci. 64:552-563.

Orskov, E. R., and I. McDonald. 1979. The estimation of protein degradability in the rumen from incubation measurements weighted according to rates of passage. J. Agric. Sci. (Camb.) 92:449-503.

Tilley, J. M. A., and R. A. Terry. 1963. A two-stage technique for the in vitro digestion of forage crops. J. Brit. Grassl. Soc. 18:104-111.

Ullerich, M. D. 2001. Effects of forage quality on performance of beef steers grazing smooth brome pastures interseeded with legumes. M. S. Thesis. Univ. Nebraska, Lincoln, NE.

Weiss, W. P. 1994. Estimation of digestibility of forages by laboratory methods. Pages 644-681 in Forage Quality, Evaluation, and Utilization. G. C. Fahey, Jr., ed. Am. Soc. Agronomy, Crop Sci. Soc. America, Soil Sci. Soc. America, Madison, WI.

Wylie, M. J., W. C. Ellis, J. H. Matis, E. M. Bailey, W. D. James, and D. E. Beever. 2000. The flow of forage particles and solutes through segments of the digestive tracts of cattle. Br. J. Nutr. 83:295-306.

Zinn, R. A., and F. N. Owens. 1986. A rapid procedure for purine measurement and its use for estimating net ruminal protein synthesis. Can. J. Anim. Sci. 66:157-166. 